\title{
TRADUZINDO UM CONTO TÃO DISTANTE
}

Karin Bakke de Araújo é mestre em Literatura pela PUC-SP e doutoranda em Letras na Universidade Presbiteriana Mackenzie de São Paulo. E-mail: bakke@aclnet.com.br

\section{Resumo}

Tradução de um conto de Franz Hohler, incluindo breves comentários sobre as escolhas feitas dentro da temática e do estilo caracterizado como prosa de criação de forte influência da linguagem poética.

\begin{abstract}
Translation of a short story by Franz Hohler, including brief comments on the choices made within the theme and the style defined as creative prose strongly influenced by poetical language.
\end{abstract}

Num grupo de estudos de tradução, coube-me traduzir um conto de um autor que me era desconhecido: Franz Hohler. O texto me atraiu e me empolgou não só pela sua beleza, mas por trazer um tema que me tocava particularmente: o da terra natal que se amplia para terras distantes, sob o signo de uma mesma verdade essencial.

Antes de pôr mãos à obra, até para entender melhor o espírito do texto e a escolha de suas palavras, procurei informações sobre o autor, para descobrir que era contemporâneo nosso, romancista, contista, dramaturgo, apresentador de programas de televisão, autor de canções, de livros infantis, roteiros de cinema e de televisão e cabareteiro. Nasceu em Biel, Suíça, em 1943. Desenvolve sua atividade em sua terra natal, onde vive na cidade de Zurique.

Não me consta que ele tenha obras traduzidas e publicadas no Brasil. Para os que dominam o alemão, achei oportuno transcrever o original do brevíssimo conto a ser traduzido, para que ele possa ser apreciado da forma como saiu das mãos de seu autor em 1998:

\section{Mein Heimatort}

Um mein Heimatort zu sehen, muss ich die Augen schliessen.

Ich glaube ihn dann in den Bergen zu erkennen, in einem Tal, wo klare Wasser unter den Felsen hervorquellen und in grossen Wasserfällen über Abgründe in die Tiefe stürzen. In der Nähe muss ein Gletscher sein, über dem sich weisse Gipfel erheben. Was für ein Rundblick von dort oben! Merkwürdig allerdings, wie nahe an meinem Heimatort das Meer liegt, ich höre seine nie erlahmende Brandung und das Gekeife von Möwen. Fischgeruch weht herüber. Woher aber der Kanonendonner? Und der aufsteigende Rauch? Sollte in meinem Heimatort Krieg sein? Es ist mir, als höre ich Kinder weinen, und ich möchte sie trösten. Nein, eine Täuschung - wenn ich genau hinhorche, höre ich Gelächter, Musik, das Geräusch von Schuhen auf einem Tanzboden. Oder ist es ein Leichenzug, der die Kirche betritt? Ja, so ist es, nicht eine Handorgel spielt, sondern eine Orgel, und als ich mich unter die Trauernden mische, stehe ich in einer Kirche in den Anden, in der sich Eingeborene leise, aber eindringlich in einer mir fremden Sprache Geschichten erzählen, und wenn ich mich geduldig zu ihnen setze, verstehe ich sie mit einem Mal, und zu meinem Erstaunen erzählen sie die Geschichten 
meiner verstorbenen Vorfahren, die auch die ihren waren, und jedes Leben war voller Mühsal, Arbeit und unerfüllter Träume, aber kein einziges Leben war ohne Hoffnung, Zuversicht und Zärtlichkeit, und es wird gar niemand begraben, sondern es wird ein Fest des Lebens gefeiert, und da sitzen sie, meine Vorfahren, unter den Eingeborenen und warten auf mich, in meinem Heimatort im Salzgeruch des Meeres, mitten im Hochland, über dem die Sturmmöwen und Steinadler ihre langen Schreie austauschen. (Hohler, 2000, p. 33-34)

O texto apresentado, apesar de estar no formato de um conto, tem a densidade de um poema, cada palavra cuidadosamente pesada, representando os sentimentos da intimidade do torrão natal universal. Minha sugestão de sua transposição para o português do Brasil ficou assim, e algumas opções serão discutidas após a sua transcrição:

Minha terra

Para ver minha terra, tenho que fechar os olhos.

Então, creio reconhecê-la nas montanhas, num vale, onde águas claras brotam debaixo das pedras e se precipitam nas profundezas em grandes cachoeiras sobre abismos. Pertinho, tem que ter uma geleira, sobre a qual se elevam cumes brancos. Que vista panorâmica se tem lá de cima! Aliás, é estranho como o mar fica perto de minha terra, escuto sua arrebentação incansável e o grasnido de gaivotas. Cheiro de peixe flutua por cima. Mas de onde vem o estrondo de canhões? E a fumaça que sobe? Será que tem guerra na minha terra? Parece-me ouvir crianças chorando, e eu as quero consolar. Não, um engano, quando apuro o ouvido, eu escuto risadas, música, o barulho de sapatos numa pista de dança. Ou é um cortejo fúnebre chegando à igreja? Pois é, é assim, não se toca acordeão, mas um órgão, e quando eu me misturo aos enlutados, estou numa pequena igreja nos Andes, na qual os nativos contam histórias baixinho, mas com insistência, numa língua estranha para mim, e, quando me sento pacientemente junto deles, de repente, consigo entendê-los, e, para meu espanto, eles contam a história de meus falecidos antepassados, que também eram os deles, e cada vida era cheia de sacrifício, trabalho e sonhos não alcançados, mas nenhuma vida era sem esperança, confiança e ternura, e ninguém está sendo enterrado, mas se celebra uma festa da vida, e lá estão eles sentados, meus antepassados, no meio dos nativos e esperam por mim, na minha terra no meio do cheiro salgado do mar, no meio das montanhas, sobre as quais as gaivotas-pardas e as águias-pesqueiras trocam seus longos trinados.

Ao fazer essa tradução, enfrentamos o desafio de tentar trazer para nossa terra que "tem palmeiras onde canta o sabiá" o sentimento de pertencimento expresso pelos Alpes suíços e pelo mundo todo. Julgamos poder afirmar que estamos diante de um texto de "prosa de criação, [que] envolve sempre o questionamento dos limites da 
linguagem e da comunicabilidade e, portanto, do difícil parâmetro da leitura e da crítica poéticas" (BARBOSA, 2002, p. 313).

A começar pelos pássaros, que não têm o nome familiar de sabiá, mas se chamam gaivotas, gaivotas-pardas e águias pesqueiras. Ao nomeá-las, Hohler certamente se referia a palavras e seres entranhados na alma popular, do mesmo modo que as nossas andorinhas, o nosso bem-te-vi, as rolinhas, cantadas desde cedo já no nosso cancioneiro infantil e cuja menção até trazem seu canto à nossa lembrança. E é desse canto presente que fala o conto poético. Como esse sentimento fica implícito no conjunto do texto, achei por bem não fazer uma recriação, colocando em seu lugar os pássaros que nos evocam tais sentimentos, mas citar suas traduções técnicas, até para situar a ação no local geográfico de origem escolhido pelo autor.

O autor transporta-se de seu rincão natal para um outro, do outro lado do mundo: ele viaja dos Alpes para os Andes. Até os nomes são parecidos, como também a paisagem. Ele introduz essa viagem poética aludindo a uma imagem de guerra, de estrondo de canhões, numa breve e forte alusão aos fenômenos que separam os povos. E esses movimentos destrutivos fazem chorar as crianças. $\mathrm{O}$ autor intruso coloca-se claramente contra esses acontecimentos ao querer consolar as crianças que choram. Nesse momento, a viagem poética se realiza e o poeta está no outro lado do mundo, irmanado com povos que nem falam a sua língua. Existe uma identidade essencial, permeada por diferenças acessórias. Essa complementaridade vem representada pela presença, na igreja andina, do órgão no lugar do acordeão encontrado na música suíça. Para traduzir Handorgel (literalmente "órgão de mão") optei pelo termo mais genérico "acordeão", mesmo tratando-se de uma referência a um signo regional suíço, e de no Brasil termos denominações para esse instrumento musical conforme a região e a época: concertina, para épocas mais remotas, sanfona, no nordeste do Brasil e gaita, na região sul. A mesma verdade essencial vem representada pelas mesmas experiências dos antepassados: a vida cheia de sacrifícios, trabalho e sonhos não alcançados. E, também, com o contraponto da mesma esperança, confiança e ternura.

Na verdade, o lar do trovador não tem barreiras. Depois de um título que parece querer evocar o cantinho restrito de um vilarejo jamais esquecido, já nas primeiras linhas, o poeta introduz uma dúvida sutil ao afirmar ser estranho como o mar fica perto de sua terra. De fato, não existe mar na Suíça. Assim, já no início do conto, insinua-se a universalidade do pertencimento abrangente do bardo, que encontra seus falecidos antepassados nas mais distantes paragens. Espaço e tempo sem fronteiras.

Essas considerações temáticas permearam a escolha dos termos escolhidos na transposição do texto para o nosso idioma, para cuja execução não poderiam faltar as 
conjecturas inevitáveis do tradutor, considerações que sempre serão de ordem pessoal e passíveis de reparos.

\section{Referências Bibliográficas}

BARBOSA, João Alexandre. Alguma crítica. Cotia - SP: Ateliê Editorial, 2002.

HOHLER, Franz. Zur Mündung - 37 Geschichten von Leben und Tod. München: Luchterhand Literaturverlag GmbH, 2000. 